\section{A Bibliography of Wheat}

A BIBLIOGRAPHY of world literature on the genetics and breeding of wheat has been issued by the Institute of Plant Industry, U.S.S.R., and forms the first volume of a new series of publications on wheat (Bull. App. Bot., Genet. and Plant Breeding, Series VA, No. 1 , pp. 136 ; 1935). In this work, the titles of articles or books appear in the language of the original contributions, and, where these have been reviewed, reference to the reviewing journal is given. The material is classified under various headings and, within each class, is arranged chronologically. An author index is included.

\section{School Nature Study}

THE July number of School Nature Study (31, No. 124), the official organ of the School Nature Study Union, contains several articles of interest. An ecological study of the plant life of the salt marshlands of south-west Sussex by A. D. French reveals four important zones, namely, the inner shore banks above high-water mark, beaches and sands above high-water mark, the interzonal region, and the marsh proper. The vegetation of these zones has been carefully examined and recorded. The animal life, too, afforded certain features of interest, and a list of birds is given. The birds of Costa Brava, Spain, have been studied by Margaret M. Hutchinson, and her observations are embodied in a short article (together with a list) in the same number. A. C. Evans, of the Rothamsted Experimental Station, contributes an article on insects and their food. The factors determining an insect's choice of plant food are examined, and the author reveals our great lack of knowledge on this problem, especially from the point of view of plants of economic value. The School Nature Study Union publishes a series of pamphlets dealing with subjects of interest to the biologist, about seventy of which are reprints from School Nature Study; five other Special Leaflets are also available. A list of the pamphlets may be obtained from Mr. E. G. Clarke, 7 Stanley Avenue, Wembley, Middlesex.

\section{Library of Conchology}

Mr. SoHtsu G. KING, the Chinese conchologist and banker, has recently given his valuable collection on conchological literature to the Science Society of China Library, Shanghai. The collection was started some twenty years ago, while he was studying Chinese Mollusca with Prof. A. W. Grabau of the University of Peking. Under their joint authorship, a book entitled "Shells of Peitaiho" was published and is now in its second edition, besides many other scientific papers. The collection consists of many valuable and rare works and several complete sets of journals. It is no exaggeration to say that the collection is unique in the Far East and invaluable to students of zoology in general and conchology in particular. The Council of the Society has passed a resolution that a special room shall be used to house the collection and shall be labelled, "Sohtsu G. King Library of Conchology". The books have already been arranged, and a complete catalogue is in preparation and will be printed and circulated to research institutions and learned societies interested. In addition to the collection, Mr. King has also given an endowment, the income of which is to be used to provide the collection with the necessary periodical literature.

\section{Records of the American Mercantile Marine}

A Co-operative project has just been launched by the Smithsonian Institution and the Works Progress Administration of the United States, having the two objects of preserving a set of standard measured drawings of American types of fishing vessels and merchant vessels, to be placed in the Watercraft Collection of the United States National Museum, and of providing work for unemployed naval architects, draughtsmen and boat builders. The work is to be known as the Historic American Merchant Marine Survey, and the information is to be gleaned from builder's models, original drawings and the actual vessels. It is to be hoped these efforts will lead to similar projects elsewhere.

\section{London Health Services}

THE Annual Report of the Ministry of Health for the year 1934-35 contains a special detailed review of the public health work carried out in London by the London County Council, the City Corporation and the Metropolitan Borough Councils. In view of the general interest of this review, it has now been issued as a separate publication, with a preface by Sir Kingsley Wood, the Minister of Health ("London Health Services". London: H.M. Stationery Office. 1s. net). The publication gives a useful survey of the division of functions among the various sanitary authorities in London, and describes the public health and poor law medical services, the food protection services, port sanitary administration, and welfare of the blind.

\section{Rubber Latex}

A REVISED edition of the book "Rubber Latex" by H. P. and W. H. Stevens has just been published by the Rubber Growers' Association, 19 Fenchurch Street, London, E.C.3, and a copy will be sent to any reader interested, on application. It deals in 224 pages with the properties, composition, coagulation, concentration, manipulation and compounding of latex and latex pastes, the vulcanisation of latex and latex products, and dipping and electro-deposition. The final chapter deals with a selected list of nearly a thousand recent British patents, and indicates the growing importance attached to the direct application of latex.

\section{'Loose-Leaf Binders' for NAture}

Messrs. Easibind, Ltd., Pilot House, Mallow Street, London, E.C.1, have sent us a specimen 'binder' made to take twenty-six issues of NATURE, without advertisements. The first and last numbers are held by stout wires passing through the centre pages of the issues, and intermediate copies are carried on thin wires which go alternately into one of two parallel slots in a metal fitting at the top and bottom of the back of the 'binder'. By this device (Continued on p. 119.) 
the bulkiness of the 'stitched' edges of a pile of loose issues is to some extent minimized. 'The 'binder' has an attractive dark green imitation leather finish, it is easy to manipulate, and is a convenient means of keeping loose issues together pending binding up a volume, or even permanently. The price of the binder is $3 s .6 d$. (4s. including postage).

\section{Civil List Pensions}

Among the Civil List pensions granted on March 12 and recently announced in a White Paper (H.M. Stationery Office, 139, price 1d.) are the following pensions for services to science : Miss A. M. Buckton, in recognition of her services to literature and of the services rendered by her father, the late Mr. George B. Buckton, to entomology, $\mathfrak{f 6 0}$; Mrs. S. I. Cunningham, in recognition of the services rendered by her husband, the late Mr. J. T. Cunningham, to zoology, $£ 90$; Miss R. M. Fleming, in recognition of her services to anthropology and geography, $£ 80$; Mrs. C. D. Hodgkinson, in recognition of the services rendered by her husband, the late Prof. W. R. Hodgkinson, to chemistry, $£ 90$; Mrs. B. Kaye, in recognition of the services rendered by her husband, the late Mr. W. J. Kaye, to the study of archæology, $£ 60$.

\section{Grants for Cancer Research}

AT the recent quarterly meeting of the Grand Council of the British Empire Cancer Campaign, grants totalling $£ 5,296$ were approved; $£ 1,187$ to Dr. A. Pollard, working at the Courtauld Institute of Biochemistry at the Middlesex Hospital, on a special scheme of biochemical research inaugurated by the Scientific Advisory Committee; $£ 150$ to Dr. F. G. Spear, working at the Strangeways Research Laboratory, Cambridge, for the purchase of a lowvoltage equipment apparatus, and $£ 700$ for the purchase of a $200 \mathrm{k} . v .10 \mathrm{~m}$.a. Greinacher set ; $£ 300$ for six months for work being carried out under the direction of Mr. F. C. Pybus through the North of England Council of the Campaign; $£ 1,256$ for fifteen months to Dr. Alexander Haddow, who is transferring from his research appointment in Edinburgh to continue special research work at The Royal Cancer Hospital (Free); $£ 320$ to Mr. Nevill Willmer, working at the Physiological Laboratory, Cambridge, for technical assistance and purchase of apparatus; and $£ 150$ for six months to Dr. Alice Leigh-Smith, working under the direction of Dr. Thomas Lumsden at the London Hospital.

\section{The Structure of Aneurin and Thiochrome}

Messrs. F. Berget and A. R. Todd point out that in their letter under this title in NaTURE of July 11 (p. 76), formulæ I and II are printed with $\mathrm{HCl}$ apparently attached to carbon atom $5^{\prime}$ of the thiazole nucleus; actually the $\mathrm{HCl}$ should be represented merely as attached to the molecule as a whole, since it cannot be allocated with certainty to any particular nitrogen atom; it cannot, of course, be attached to a carbon atom. In formula III a single bond should be inserted between $\mathrm{C}_{5}$ of the pyrimidine ring and the thiazole nitrogen.
Applications are invited for the following appointments, on or before the dates mentioned :

A lecturer in biology in The Polytechnic, Regent Street, London, W.1-The Director of Education (July 20).

A lecturer in mechanical engineering in the Burnley Municipal College-The Director of Education, Education Offices, Burnley (July 20).

An assistant in the Mechanical Engineering Department and an assistant in the Electrical Engineering and Physics Department of the Coventry Technical College-The Director of Education, Council House, Coventry (July 22).

Mechanical engineers for the Supply Board Technical Establishment under the Director of Ordnance Factories-The Under-Secretary of State (C.5), War Office, London, S.W.I (July 24).

Four instructors in motor engineering in the South. East Essex Technical CoHege-The Clerk to the Governors, Five Elms Council School, Wood Lane, Dagenham (July 24).

A lecturer in mathematics, and three lecturers in engineering, in the Acton Technical College, High Street, Acton, 3-The Principal (July 24).

A lecturer and deputy director of the Department of Anatomy in the St. Thomas's Hospital Medical School, London, S.E.1-The Dean (July 24).

An assistant lecturer in physics in the University of Manchester-The Registrar (July 29).

A lecturer (Grade IIb) in electrical engineering in the University of Birmingham-The Secretary (July 29).

Junior scientific officers in the Directorate of Scientific Research of the Air Ministry-The Chief Superintendent, Royal Aircraft Establishment, South Farnborough, Hants (July 31).

A head of the Department of Mechanical Engineering in the Bradford Technical College-The Principal (July 31).

A civilian scientific officer in the Admiralty Scientific Pool-The Secretary of the Admiralty (C.E. Branch), Whitehall, S.W.1 (July 31) (quote C.E. $3709 / 36)$.

A demonstrator in chemistry in the University of Aberdeen-The Secretary (August 8).

A temporary assistant lecturer in chemistry in the University of Manchester-The Registrar (August 8).

Two part-time demonstrators in inorganic chemistry in the University of Leeds-The Registrar (August 15).

A lecturer in fuel technology in the University of Sheffield-The Registrar (August 15).

A lecturer in metal mining in the University of Birmingham-The Secretary (August 15).

A University reader in physiology in the London Hospital Medical College--The Academic Registrar, University of London, S.W.7 (September 11).

A part-time lecturer in science in St. Paul's Training College, Selly Park, Birmingham-The Principal.

A part-time demonstrator in mathematics in University College, Southampton-The Registrar.

An assistant lecturer in geography in University College, Hull-The Registrar. 